\title{
HUBUNGAN KEBIASAAN MEROKOK DI DALAM RUMAH DENGAN KEJADIAN PENYAKIT INFEKSI SALURAN PERNAPASAN AKUT (ISPA) PADA BALITA DI PUSKESMAS BATURETNO I
}

\author{
Budi Kristanto', Ambrosius Setya Widri Hanggara ${ }^{2}$
}

\begin{abstract}
Background : deaths due to ARI disease in infants reaching 12.4 million in toddlers $0-5$ year age group every year worldwide, two thirds are babies, that is $0-1$ years old and $80.3 \%$ of deaths occur in developing countries (Kemenkes, 2010). The prevalence of ARI occurrence in Indonesia is $25.0 \%$ (Riskesdas, 2013: 23). Smoking habits of parents in the home make toddlers as passive smokers are always exposed to cigarette smoke. Research purposes : to determine the relationship between exposure to secondhand smoke with the incidence of acute respiratory infections in infants.

Subject : toddlers who checked at Puskesmas Baturetno 1 in February-March 2017 were diagnosed with acute respiratory infection.

Methods : this research use correlation research design with cross sectional method. The population is all parents of children under five who checked their children to Baturetno I Puskesmas in February and March with an acute respiratory infection diagnosis, a total of 20 respondents. Control group of children who did not experience acute respiratory tract infection of 20. Researchers used questionnaire tools. Data obtained then tabulated and analyzed using SPSS 16 for Windows.

Results : 15 children (75\%) were exposed to cigarette smoke and 5 children $(25 \%)$ were not exposed to cigarette smoke. There was an association between ARI occurrence and exposure of cigarette smoke to under-five children at Puskesmas Baturetno I with p: $0.011<\alpha: 0.05$

Conclusion : There is a correlation between ARI occurrence and exposure of tobacco smoke in infants at Puskesmas Baturetno I.
\end{abstract}

Keywords: smoking, acute respiratory infections, less than five years

\section{PENDAHULUAN}

Infeksi Saluran Pernafasan Akut (ISPA) adalah infeksi akut yang melibatkan organ saluran pernapasan bagian atas dan saluran pernapasan bagian bawah yang disebabkan oleh virus, jamur dan bakteri. ISPA akan menyerang host apabila ketahanan tubuh (immunologi) menurun pada bayi di bawah lima tahun dan bayi merupakan salah satu kelompok yang memiliki sistem kekebalan tubuh yang masih rentan terhadap berbagai penyakit (Yusuf, 2008 ).

Sampai saat ini ISPA masih menjadi masalah kesehatan dunia. World Health Organization (WHO) menyebutkan bahwa tahun 2011 di New York jumlah penderita ISPA adalah 48.325 anak dan memperkirakan di negara berkembang berkisar 30-70 kali lebih tinggi dari negara maju dan diduga $20 \%$ dari bayi yang lahir di negara berkembang gagal mencapai usia 5 tahun dan 25-30\% dari kematian anak disebabkan oleh ISPA. Hal ini dapat dilihat dari tingginya angka kesakitan dan kematian akibat ISPA. Kematian akibat penyakit ISPA pada balita mencapai 12.4 juta pada balita golongan umur 0-5 tahun setiap tahun diseluruh dunia, dimana dua pertiganya adalah bayi, yaitu golongan umur 0-1 tahun dan sebanyak $80.3 \%$ kematian ini terjadi di negara berkembang (Depkes RI, 2009).

Prevalensi kejadian ISPA di Indonesia adalah $25.0 \%$ persen 
(Riskesdas, 2013). ISPA menyebabkan kematian bayi dan balita cukup tinggi yaitu kira-kira 1 dari 4 kematian terjadi. Setiap anak mengalami 3-6 episode ISPA setiap tahunnya. Antara 40-60\% dari kunjungan di Puskesmas adalah karena penyakit ISPA (Depkes RI, 2009).

ISPA dapat disebabkan oleh tiga faktor, yaitu faktor individu anak, faktor perilaku dan faktor lingkungan. Faktor individu anak meliputi: umur anak, berat badan lahir, status gizi, vitamin A dan status imunisasi. Faktor perilaku meliputi perilaku pencegahan dan penanggulangan ISPA pada bayi atau peran aktif keluarga/masyarakat dalam menangani penyakit ISPA. Faktor lingkungan meliputi : pencemaran udara dalam rumah (asap rokok dan asap hasil pembakaran bahan bakar untuk memasak dengan konsentrasi yang tinggi), ventilasi rumah dan kepadatan hunian (Prabu, 2009).

Merokok merupakan kegiatan yang berbahaya bagi kesehatan tubuh karena menurut badan kesehatan dunia (WHO) rokok merupakan zat adiktif yang memiliki kandungan kurang lebih 4000 elemen, dimana 200 elemen di dalamnya berbahaya bagi kesehatan tubuh menambahkan bahwa racun yang utama dan berbahaya pada rokok antara lain tar, nikotin, dan karbon monoksida. Racun itulah yang kemudian akan membahayakan kesehatan seorang perokok (Esler , 2006).

Dampak rokok tidak hanya mengancam bagi perokok tetapi juga orang disekitarnya atau perokok pasif. Analisis WHO menunjukkan bahwa efek buruk asap rokok lebih besar bagi perokok pasif dibandingkan perokok aktif. Ketika perokok membakar sebatang rokok dan menghisapnya, asap yang dihisap oleh perokok disebut asap utama, dan asap yang keluar dari ujung rokok (bagian yang terbakar) dinamakan side stream smoke atau asap samping. Asap samping ini terbukti mengandung lebih pembakaran tembakau dibanding asap utama. Asap ini mengandung karbon monoksida 5 kali lebih besar, tar dan nikotin 3 kali lipat, amonia 46 kali lipat, nikel 3 kali lipat, nitrosamine sebagai penyebab kanker kadarnya mencapai 50 kali lebih besar asap sampingan dibanding dengan kadar asap utama (Esler, 2006).

Kebiasaan merokok orang tua di dalam rumah menjadikan balita sebagai perokok pasif yang selalu terpapar asap rokok. Rumah yang orang tuanya mempunyai kebiasaan merokok berpeluang meningkatkan kejadian ISPA sebesar 7.83 kali dibandingkan dengan rumah balita yang orang tuanya tidak merokok di dalam rumah. Sementara itu jumlah perokok dalam suatu keluarga cukup tinggi (Esler, 2006).

Retna dan Fajri (2015) dalam penelitiannya menyebutkan bahwa dari 26 pasien pneumonia, 23 diantaranya memiliki anggota keluarga perokok aktif. Penelitian yang dilakukan oleh Winarni (2010) juga menyebutkan bahwa perilaku merokok berhubungan dengan kejadian ISPA pada balita di wilayah kerja Puskesmas Sempor II.

Kabupaten Wonogiri adalah salah satu kabupaten dengan insiden ISPA cukup tinggi. Data dari Dinas Kesehatan Kabupaten Wonogiri pada tahun 2010, jumlah insidensi Infeksi Saluran Pernapasan Akut Pneumonia pada balita sebanyak 4.643 (Dinas Kesehatan Kabupeten Wonogiri, 2013). Khusus di wilayah Kecamatan Baturetno, dari data yang diperoleh dari Puskesmas Baturetno I, dari bulan Januari sampai Desember 2016 ditemukan kejadian ISPA pneumonia pada balita sebanyak 245 kejadian dan ISPA bukan pneumonia sebanyak 423 kejadian.

Berdasarkan uraian di atas maka penulis tertarik untuk melakukan 
penelitian tentang hubungan kebiasaan merokok di dalam rumah dengan kejadian penyakit Infeksi Saluran Pernapasan Akut (ISPA) pada balita.

\section{TUJUAN PENELITIAN}

Secara umum penelitian ini bertujuan untuk mengetahui hubungan kebiasaan merokok di keluarga dengan kejadian penyakit Infeksi Saluran Pernafasan Akut (ISPA) Balita di Puskesmas Baturetno I, dengan tujuan khususnya untuk mengetahui gambaran kebiasaan merokok di dalam rumah pada pada keluarga balita dengan ISPA di Puskesmas Baturetno I dan mengetahui gambaran angka kejadian ISPA pada balita di Puskesmas Baturetno I.

\section{METODE/DESAIN PENELITIAN}

Pada penelitian ini menggunakan desain penelitian korelasi dengan pendekatan metode cross sectional untuk mengetahui hubungan kebiasaan merokok di dalam rumah dengan kejadian penyakit Infeksi Saluran Pernapasan Akut (ISPA) pada balita di Puskesmas Baturetno I.

\section{POPULASI, SAMPEL DAN TEHNIK SAMPLING}

Populasi dalam penelitian ini adalah seluruh balita usia 0-5 tahun yang diperiksakan di Klinik Ibu Anak dengan diagnosa medis ISPA pada bulan Februari- Maret 2017. Sampel penelitian ini adalah semua anak usia 0-5 tahun dengan diagnosa medis ISPA dari Bulan Februari sampai dengan Maret 2017 yang kebetulan periksa di Puskesmas Baturetno I. Adapun teknik sampling yang digunakan adalah teknik accidental.

\section{HASIL PENELITIAN}

1. Distribusi frekuensi

Tabel 1.

Distribusi Frekuensi

Riwayat ISPA

\begin{tabular}{ccc}
\hline Kategori & $\mathrm{f}$ & $\%$ \\
\hline ISPA & 20 & 50 \\
Tidak ISPA & 20 & 50 \\
\hline Jumlah & 40 & 100 \\
\hline
\end{tabular}

Dari tabel di atas dapat diketahui bahwa jumlah balita dengan ISPA dan tidak ISPA berimbang yaitu masing-masing 20 atau $50 \%$. Hal tersebut dikarenakan peneliti mengambil responden sejumlah 20 untuk balita dengan ISPA dan 20 balita dengan tidak ISPA.

Tabel 2.

Distribusi Frekuensi

Paparan Asap Rokok

\begin{tabular}{ccc}
\hline Paparan & $\mathrm{f}$ & $\%$ \\
\hline Terpapar & 22 & 55 \\
Tidak terpapar & 18 & 45 \\
\hline Jumlah & 40 & 100 \\
\hline
\end{tabular}

Dari tabel di atas terlihat bahwa mayoritas responden yaitu 55\% mendapatkan paparan asap rokok, sedangkan sisanya $45 \%$ tidak mendapatkan paparan asap rokok.

2. Hasil Analisa

a. Tabulasi Silang

Tabel 3.

Tabulasi Silang Kejadian ISPA dengan Paparan Asap Rokok

\begin{tabular}{|c|c|c|c|}
\hline \multirow[b]{2}{*}{$\begin{array}{c}\text { Riwa } \\
\text { yat } \\
\text { ISPA }\end{array}$} & \multicolumn{2}{|c|}{ Paparan Rokok } & \multirow[b]{2}{*}{ Tota } \\
\hline & $\begin{array}{c}\text { Ada } \\
\text { Perokok }\end{array}$ & $\begin{array}{c}\text { Tidak } \\
\text { Ada } \\
\text { Perokok }\end{array}$ & \\
\hline ISPA & 15 & 5 & 20 \\
\hline $\begin{array}{l}\text { Tidak } \\
\text { ISPA }\end{array}$ & 7 & 13 & 20 \\
\hline Total & 22 & 18 & 40 \\
\hline
\end{tabular}


b. Hasil Uji Korelasi dengan Chi Square

Hasil analisis dengan SPSS

16 For Windows diperoleh

hasil Pearson Chi-Square

0.011 atau $p<0.05$. Dapat disimpulkan bahwa terdapat hubungan antara kejadian ISPA dengan paparan asap rokok. Hasil analisis Odds Ratio diperoleh OR : 5.57, yang bermakna bahwa balita yang terpapar asap rokok memiliki resiko ISPA 5.57 kali dibandingkan balita yang tidak terpapar asap rokok.

\section{PEMBAHASAN}

1. Paparan Asap Rokok

Pada penelitian ini diperoleh informasi bahwa dari 20 responden dengan riwayat ISPA $15(75 \%)$ terpapar asap rokok sedangkan 5 (25\%) tidak terpapar asap rokok. Sedangkan pada responden yang tidak ISPA 7 (35\%) terpapar asap rokok, sedangkan 13 (65\%) tidak terpapar asap rokok. Sedangkan informasi berdasarkan frekuensi paparan asap rokok dari 20 responden balita dengan riwayat ISPA $3(15 \%)$ terpapar 1 kali sehari, $5(25 \%)$ terpapar 2 kali sehari, $3(15 \%)$ terpapar 3 kali sehari dan 9 (45\%) terpapar 4 kali atau lebih dalam sehari. Sedangkan untuk balita tidak ISPA 14 (70\%) tidak ada paparan asap rokok, 4 (20\%) terpapar 1 kali sehari dan 2 (10\%) terpapar 2 kali sehari.

Dari data di atas menunjukkan bahwa kelompok balita dengan ISPA mayoritas (75\%) terpapar asap rokok, sedangkan pada kelompok tidak ISPA lebih sedikit, yaitu $35 \%$. Hal tersebut dapat dijelaskan seperti yang disampaikan oleh Tirtosastro dan Murdiyanti (2010), kandungan kimia tembakau yang sudah teridentifikasi jumlahnya mencapai 2.500 komponen. Dari jumlah tersebut 1.100 komponen diturunkan menjadi komponen asap secara langsung dan 1.400 lainnya mengalami dekomposisi atau terpecah, bereaksi dengan komponen lain dan membentuk komponen baru. Di dalam asap sendiri terdapat 4.800 macam komponen kimia yang telah teridentifikasi. Telah diidentifikasi komponen kimia rokok yang berbahaya bagi kesehatan, yaitu: tar, nikotin, gas $\mathrm{CO}$, dan $\mathrm{NO}$ yang berasal dari tembakau. Selain itu juga bahan-bahan berbahaya yang terbentuk saat penanaman, pengolahan, dan penyajian dalam perdagangan, yaitu residu pupuk dan pestisida, TSNA (Tobacco Spesific Nitrosamine), B-a-P (Benzo-aPyrene), dan NTRM (NonTobacco Related Material).

Beberapa penyakit yang diakibatkan dari kebisaan menghisap rokok mungkin saja tidak terjadi dalam waktu singkat namun memberikan perokok potensi yang lebih besar. Syahriyanti (2010), menyebutkan akibat negatif dari rokok antara lain adalah : impotensi karena dengan merokok dapat menyebabkan penurunan seksual karena aliran darah ke penis berkurang sehingga tidak terjadi ereksi. Dampak yang lain adalah osteoporosis dimana karbon monoksida dalam asap rokok dapat mengurangi daya angkut oksigen darah perokok sebesar 15 persen, mengakibatkan kerapuhan tulang sehingga lebih mudah patah dan membutuhkan waktu 80 persen lebih lama penyembuhan. Dampak yang lain adalah pada kehamilan, dimana merokok selama kehamilan menyebabkan pertumbuhan janin lambat dan dapat meningkatkan resiko berat badan lahir rendah (BBLR). 
Resiko keguguran pada wanita perokok 2-3 kali lebih sering karena karbon monoksida dalam asam rokok dapat menurunkan kadar oksigen (Zulkifli, 2008).

Dampak yang sangat berbahaya yang lain dari merokok adalah penyakit jantung koroner. Penyakit jantung adalah salah satu penyebab kematian utama di Indonesia. Sekitar 40 persen kematian disebabkan oleh gangguan sirkulasi darah, dimana 2.5 juta adalah penyakit jantung koroner. Penyakit Pembuluh Darah Perifer (PPDP) yang mengakibatkan pembuluh darah arteri dan vena di tungkai bawah atau tangan sering ditemukan pada dewasa muda perokok berat, biasanya akan berakhir dengan amputasi (Zulkifli, 2008).

Sistem pernapasan juga akan mengalami gangguan dengan merokok. Kerugian jangka pendek sistem pernapasan akibat rokok adalah kemampuan rokok untuk membunuh serabut getar (silia) disaluran pernapasan. Ini adalah awal dari bronkitis, iritasi, batuk. Sedangkan untuk jangka panjang berupa kangker paru, emfisema, atau hilangnya elasitas paru-paru, dan bronkitis kronis (Zulkifli, 2008).

Dari uraian di atas, dapat disimpulkan dampak rokok dapat berakibat menimbulkan berbagai penyakit seperti: impotensi, osteoporosis, pada kehamilan, jantung koroner dan sistem pernapasan. Salah satu wujud gangguan pernafasan yaitu adalah infeksi saluran pernafasan akut atau ISPA (Zulkifli, 2008).

Menurut Syauqia (2011) faktorfaktor yang mempengaruhi penyakit ISPA sangat kompleks. Rokok bukan hanya menjadi masalah bagi perokok aktif tetapi juga perokok pasif (Kemenkes RI, 2011). Berdasarkan hasil penelitian Nasution et al. (2009) serta Winarni et al. (2010), didapatkan hubungan yang bermakna antara pajanan asap rokok dengan kejadian ISPA.

Salah satu faktor lingkungan yang menjadi faktor determinan timbulnya ISPA adalah paparan asap rokok. Paparan asap rokok, terutama pada balita menjadi faktor yang berpengaruh pada kejadian ISPA pada balita. Hal tersebut dapat terlihat pada penelitian ini, dimana diperoleh informasi bahwa dari 20 responden dengan riwayat ISPA $15(75 \%)$ terpapar asap rokok sedangkan 5 (25\%) tidak terpapar asap rokok. Sedangkan pada responden yang tidak ISPA 7 (35\%) terpapar asap rokok, sedangkan 13 (65\%) tidak terpapar asap rokok. Dari informasi tersebut diperoleh informasi bahwa mayoritas anak dengan ISPA terpapar asap rokok (75\%) sedangkan sebaliknya pada kelompok tidak ISPA mayoritas (65\%) tidak terpapar asap rokok.

2. ISPA pada Balita

Dari penelitian ini diperoleh informasi bahwa mayoritas responden balita pada usia 13-36 bulan yaitu 23 (57.5\%), sedangkan pada kelompok usia 37-60 bulan sejumlah 16 (40\%) dan $0-12$ bulan 1 (2.5\%). Sedangkan pada kelompok anak dengan riwayat ISPA sejumlah 20 anak, diperoleh informasi bahwa 11 (55\%) pada usia 13-36 bulan, 8 (40\%) pada kelompok usia 37-60 bulan dan 1 (5\%) pada kelompok usia 0-12 bulan.

Dari data di atas dapat diperoleh informasi bahwa kejadian ISPA tertinggi pada kelompok usia 1336 bulan (55\%). Dari hasil penelitian ini dapat memberikan penjelasan bahwa salah satu faktor yang memberikan kontribusi kejadian ISPA adalah 
usia. Seperti diuraikan oleh Syauqia (2011) faktor- yang mempengaruhi penyakit ISPA salah satunya adalah umur. Risiko untuk terkena ISPA pada anak yang lebih muda umurnya lebih besar dibandingkan dengan anak yang lebih tua umurnya. Dari hasil uji statistik menunjukkan ada pengaruh umur terhadap kejadian ISPA pada anak balita.

Menurut Syauqia (2011), Infeksi Saluran Pernapasan Akut sering disingkat dengan ISPA. ISPA meliputi tiga unsur yakni infeksi, saluran pernapasan dan akut. Infeksi saluran pernafasan akut merupakan kelompok penyakit yang komplek dan heterogen, yang disebabkan oleh berbagai etiologi.

Penyebab dari ISPA terdiri dari 300 lebih jenis virus, bakteri, riketsia dan jamur. Virus penyebab ISPA antara lain golongan mikrovirus (termasuk di dalamnya virus influenza, virus para-influenza dan virus campak), dan adenovirus. Bakteri penyebab ISPA misalnya: Streptokokus hemolitikus, Stafilokokus, Pneumokokus, Hemofilus influenza, Bordetella pertusis dan Korinebakterium diffteria. Bakteri tersebut di udara bebas akan masuk dan menempel pada saluran pernafasan bagian atas yaitu tenggorokan dan hidung. Biasanya bakteri tersebut menyerang anak-anak yang kekebalan tubuhnya lemah. Golongan virus penyebab ISPA antara lain golongan miksovirus (termasuk di dalamnya virus para-influenza, virus influenza, dan virus campak) dan adenovirus. Virus para-influenza merupakan penyebab terbesar dari sindroma batuk rejan, bronkiolitis dan penyakit demam saluran nafas bagian atas. Pada bayi dan anak-anak, virus influenza merupakan penyebab terjadinya lebih banyak penyakit saluran nafas bagian atas dari pada saluran nafas bagian bawah. Jumlah penderita infeksi pernapasan akut sebagian besar terjadi pada anak. Infeksi pernapasan akut mempengaruhi umur anak, musim, kondisi tempat tinggal, dan masalah kesehatan yang ada (Misnudiaru, 2008).

3. Hubungan Paparan Asap Rokok dengan Kejadian ISPA pada Balita

Dari penelitian ini diperoleh hasil bahwa terdapat hubungan yang signifikan antara kejadian ISPA dengan paparan asap rokok pada balita dengan $p$ value $0.011<\alpha$ 0.05. Dari hasil analisis Odds Ratio diperoleh OR : 5.57, yang bermakna bahwa balita yang terpapar asap rokok memiliki resiko ISPA 5.57 kali dibandingkan balita yang tidak terpapar asap rokok. Hal tersebut menguatkan hasil pada penelitian-penelitian sebelumnya terkait dengan dampak pajanan asap rokok dengan kejadian ISPA pada balita.

Balita dalam konteks penelitian ini merupakan perokok pasif, sedangkan yang dimaksud dengan perokok pasif adalah seseorang yang tidak merokok tetapi secara tidak sengaja ikut menghisap asap rokok disekitar perokok. Perokok pasif lebih berisiko daripada perokok aktif. Hal ini disebabkan karena perokok pasif menghisap rokok dari aliran utama atau mainstream smoke yaitu asap rokok yang dikeluarkan oleh perokok dan asap aliran sisi atau sidestream smoke yaitu asap yang keluar dari ujung rokok yang dibakar. Asap aliran sisi ini mengandung 2 kali lebih banyak nikotin, 3 kali lebih tar, 5 kali lebih 
banyak karbonmonoksida (Esler, 2006).

Perokok pasif akan mengalami sakit dan pedih mata, bersin dan batuk-batuk, sakit kerongkongan, sakit kepala, masalah pernafasan termasuk radang paru-paru dan bronkhitis, meningkatkan risiko kanker paru dan penyakit jantung. Menurut Zulkifli (2008) bahwa merokok memberikan efek negatif. Asap rokok dapat menghambat pertumbuhan janin dalam rahim ibu, anak-anak perokok lebih sering terserang penyakit paru - paru, batuk-batuk, influenza dan sakit tenggorokan. Mereka juga sering jatuh sakit. Hal tersebut dikuatkan pada penelitian ini, dimana terdapat hubungan antara paparan asap rokok dengan kejadian ISPA pada balita.

Hal tersebut sesuai dengan penelitian Winarni, et al. (2010), dimana diperoleh hasil terdapat hubungan yang signifikan antara perilaku merokok orang tua dan anggota keluarga yang tinggal dalam satu rumah dengan kejadian ISPA pada balita dengan $p: 0.000<\alpha: 0.005$. Penelitian yang dilakukan Zuhriyah (2015) juga diperoleh hasil bahwa kebiasaan merokok anggota keluarga tanpa memperhatikan lingkungan sekitar selain dapat menimbulkan masalah bagi perokok itu sendiri juga dapat menimbulkan masalah bagi orang lain, termasuk balita yang tinggal bersama. Salah satu masalah yang sering sekali timbul pada balita akibat paparan asap rokok adalah Infeksi Saluran Pernapasan Akut (ISPA). Hasil penelitian ini dapat disimpulkan bahwa kebiasaan merokok anggota keluarga dengan kejadian penyakit ISPA pada anak balita mempunyai hubungan yang bermakna. Penelitian ini membuktikan bahwa perilaku merokok orang disekitar balita berhubungan dengan kejadian ISPA. Dari hasil analisis data diperoleh Dari hasil analisis Odds Ratio diperoleh OR : 5.57, yang bermakna bahwa balita yang terpapar asap rokok memiliki resiko ISPA 5.57 kali dibandingkan balita yang tidak terpapar asap rokok.

\section{KESIMPULAN}

1. Kejadian ISPA pada anak yang periksa di klinik KIA Puskesmas Baturetno I bulan Februari dan Maret 2017 sebanyak 20 anak, dimana 15 anak (75\%) terpapar asap rokok dan 5 anak (25\%) tidak terpapar asap rokok.

2. Mayoritas responden balita pada usia 13-36 bulan yaitu 23 (57.5\%), sedangkan pada kelompok usia 37-60 bulan sejumlah $16 \quad(40 \%)$ dan $0-12$ bulan $1(2.5 \%)$. Sedangkan pada kelompok anak dengan riwayat ISPA sejumlah 20 anak, diperoleh informasi bahwa 11 (55\%) pada usia 13-36 bulan, 8 (40\%) pada kelompok usia 37-60 bulan dan 1 (5\%) pada kelompok usia 0-12 bulan. Dapat disimpulkan bahwa kejadian ISPA tertinggi pada kelompok usia 13-36 bulan (55\%).

3. Terdapat hubungan antara kejadian ISPA dengan paparan asap rokok ( $p$ value 0.011 ). Dari hasil analisis Odds Ratio diperoleh OR : 5.57, yang bermakna bahwa balita yang terpapar asap rokok memiliki resiko ISPA 5.57 kali dibandingkan balita yang tidak terpapar asap rokok.

\section{SARAN}

1. Bagi masyarakat Bagi masyarakat, terutama orang tua dari balita hendaknya melakukan upaya pencegahan paparan asap rokok pada balitanya, sehingga salah satu 
faktor resiko terjadinya ISPA dapat dihindari.

2. Bagi Profesi Perawat

Perawat khususnya perawat komunitas dapat lebih meningkatkan perannya terutama mengedukasi masyarakat terkait bahaya rokok bagi kesehatan.

3. Bagi Dinas Kesehatan Kabupaten Wonogiri

Dinas kesehatan beserta perangkatnya dapat lebih meningkatkan upaya kesehatan masyarakat untuk memberikan kesadaran pada masyarakat terkait bahaya rokok.

\section{DAFTAR PUSTAKA}

Ariani, P. 2014. Metodologi Penelitian Kebidanan dan Kesehatan Reproduksi. Nuha Medika,Yogyakarta.

Depdikbud. 1990. Kamus Besar Bahasa Indonesia. Balai Pustaka Depdikbud, Jakarta.

Depkes RI. 2009. Profil Kesehatan Indonesia 2008. Jakarta.

Manajemen Sumber Dedoman
Manusia (SDM) Kesehatan
dalam Penaggulangan Bencana
, Jakarta

Dinas Kesehatan Kabupaten Wonogiri. 2013. Profil Kesehatan Kabupaten Wonogiri 2012.

Essler, G. 2006. "United States of America v. Philip Morris et al: Final Opinion of Judge Gladys Kessler" (PDF). United States District Court for the District of Columbia.

Kemenkes RI. 2011. Pedoman Pengendalian Infeksi Saluran Pernapasan Akut. Kementerian Kesehatan Republik Indonesia, Dirjen pengendalian Penyakit dan Penyehatan Lingkungan. Jakarta.

\begin{tabular}{l}
$2011 . \quad$ Pedoman \\
\hline Pengendalian Infeksi Saluran \\
Pernapasan Akut. Bakti Husada, \\
Jakarta.
\end{tabular}

- 2013. Riset Kesehatan Dasar : Risekesdas 2013. Jakarta

Marhamah. 2013. Faktor yang Berhubungan Dengan Kejadian ISPA Pada Anak Balita Di Desa Bontongan Kabupaten Enrekang.http://www.asikbelajar. com. diakses tanggal 10 november 2016.

Misnudiaru. 2008. Penyakit Infeksi Saluran Napas Pneumonia. Obor Pupulan, Jakarta

Prabu. 2009. Hubungan Antara Lingkungan Rumah Fisik Rumah Tinggal dengan Kejadian ISPA di Kampung Kedeug Watu. http// www.jurnal.lipi.go.id. Diakses pada tanggal 4 November 2016.

Retna dan Fajri. 2015. Hubungan Perilaku Merokok Orang Tua dengan Kejadian ISPA Pada Balita di Wilayah Kerja Puskesmas Sempor II. http// www.jurnal.lipi.go.id. Diakses pada tanggal 4 November 2016.

Syahriyanti, E. 2010. Stop Merokok. Yogyakarta: Dara IImu

Syauqia, D. 2011. ISPA Gangguan Pada Anak. Medical Dusk, Jakarta.

Tirtosastro, S. dan A. S. Murdiyanti. 2010. Kandungan Kimia Tembakau dan Rokok. Malang: Balai Penelitian Tanaman Tembakau

Winarni, et al. 2010. Hubungan Perilaku Merokok Orang Tua dan Anggota Keluarga yang Tinggal dalam Satu Rumah dengan Kejadian ISPA pada Balita di Wilayah Kerja Puskesmas Sempor II Kabupaten Kebumen Tahun 2009. Jurnal IImiah Kesehatan Keperawatan.

Yusuf. 2008. Hubungan Sanitasi Rumah Secara Fisik Dengan Kejadian ISPA Pada Anak Balita. Arga Publishing, Jakarta. 
Zuhriyah. 2015. Gambaran Kebiasaan Merokok Anggota Keluarga

Pada Kejadian ISPA Balita Di Kabupaten Gresik. http://pustaka.pps.unsri.ac.id.

Diakses tanggal 10 november 2016.

Zulkifli. 2008. Thanks For Smoking.

Pinus Book Publisher, Bandung.

${ }^{1}$ Dosen Akper Panti Kosala

Surakarta

${ }^{2}$ Mahasiswa Akper Panti Kosala

Surakarta 